\title{
Geological Association of Canada 1998 Annual Technical Meeting Newfoundland Section
}

\begin{abstract}
S
Regional tectonics of Newfoundland and Labrador New interpretations
\end{abstract}

\author{
February 23-24, 1998 \\ Department of Earth Sciences \\ Memorial University of Newfoundland \\ St. John's, Newfoundland
}




\title{
Plutonic rocks of the Island Harbour Bay-Kaipokok Bay area, Makkovik Province, Labrador: petrochemistry and tectonic setting
}

\author{
S. Barr', C. White', J. Ketchum ${ }^{3}$ and N. Culshaw'
}

'Department of Geology, Acadia University, Wolfville, Nova Scotia BOP IXO, Canada

${ }^{2}$ Department of Natural Resources, P.O. Box 698, Halifax, Nova Scotia B3J 2T9, Canada

${ }^{3}$ Department of Earth Sciences, Memorial University of Newfoundland, St. John's, Newfoundland A1B 3X5, Canada

'Department of Earth Sciences, Dalhousie University, Halifax, Nova Scotia B3H 3J5, Canada

Detailed mapping of the shoreline section from the Hares Islands through Island Harbour Bay and Kaipokok Bay to Cape Aillik has provided a new perspective on the nature of plutonic units in the Kaipokok domain of the Makkovik Province. Based on petrological studies and U-Pb geochronology, it is clear that, in addition to the subduction-related ca. 1850 to $1885 \mathrm{Ma}$ Island Harbour Bay Plutonic Suite, two episodes of post-tectonic A-type plutonism also extend across this part of the Kaipokok domain.

The Island Harbour Bay Plutonic Suite (IHBPS) includes variably deformed and recrystallized units ranging in composition from quartz diorite to granite. The oldest components may be the Antons Island Quartz Diorite (ca. $1884 \mathrm{Ma}$ ) and K-feldspar porphyroblastic granodioritic sheets (ca. $1871 \mathrm{Ma}$ ) in reworked Archean gneissic basement of the area. However, the two major components of the IHBPS in the map area are the Abels Harbour granite (ca. $1857 \mathrm{Ma}$ ) and the Groovy Island granodiorite/tonalite. The IHBPS appears to be calc-alkalic and emplaced at a deep crustal level in a continental margin subduction zone.

The Hares Islands granite, previously dated at ca. 1805 $\mathrm{Ma}$ and included in the IHBPS, appears instead to be part of a younger suite of mainly granitic plutons that includes the Drunken Harbour granite $(1784+5 /-4 \mathrm{Ma})$, the previously dated Brumwater granite in Kaipokok Bay (ca. $1794 \mathrm{Ma}$ ), and other granitic bodies defined during the present study. These units crosscut gneisses, preserve igneous textures, and locally display magmatic foliation. They are associated and probably 00 -magmatic with gabbroic and dioritic rocks and granitic porphyries, and have A-type petrological character. Most of the pluton formerly included in the IHBPS in the Cape Roy area on the west side of Kaipokok Bay is interpreted to belong to this suite, which is hence termed the Cape Roy Suite. Although similar in age (previously dated at ca. $1802 \mathrm{Ma}$ ) the Long Island quartz monzodiorite in the Kaipokok Bay area is strongly sheared, and intruded by undeformed gabbroic, dioritic and granitic rocks of the Cape Roy suite.

Even younger post-tectonic A-type granites include the Blacklers Bight granite (ca. $1715 \mathrm{Ma}$ ), also previously included in the IHBPS, and other plutons characterized by the presence of fluorite and alkalic mafic minerals such as riebeckite and arfedsonite. These plutons may be related to the Strawberry Intrusive Suite of the Aillik domain.

\section{The Upper Ordovician Lawrence Harbour Formation of the Exploits Subzone: new perspectives on structure, stratigraphy and geochemistry}

James Carter

\section{Department of Earth Sciences, Memorial University of Newfoundland, St. John's, Newfoundland A1B 3X5, Canada}

The Upper Ordovician Lawrence Harbour Formation is a significant lithostratigraphic and biostratigraphic marker horizon found throughout the Exploits Subzone. In the Grand Falls-Windsor-Badger region the Lawrence Harbour Formation grades from graptolitic siliceous black shale to dark grey silty shale and silty shale, from base to top. It is conformably underlain by grey bioturbated chert and conformably overlain by sandstone and siltstone turbidites of the Point Leamington Formation. Extensive structural reworking of these units commonly produces complex regional outcrop patterns. Detailed outcrop-scale structural maps define reverse faults that cross-cut limbs of open to close folds. These structures ap- pear to have been followed by a later stage of deformation that steepened the thrust faults. Regional penetrative cleavage is observed as axial planar to the early Fl-folds.

Geochemical and lithological variation has been defined vertically through the shale transition and appears to be related to increasing grain size from base to top of the shales. The Lawrence Harbour Formation, sampled from Notre Dame Bay to Bay D'Espoir, shows no marked lateral variation in geochemistry. These trends support a coarsening-upward sequence for the shales, and appear to support the model of deposition within a single interconnected basin for the Lawrence Harbour Formation.

\section{A history of the Paleoproterozoic Makkovik Province (Labrador) \\ Nicholas Culshaw', Gavin Sinclair' ${ }^{1}$ John Ketchum² and Sandra Barr ${ }^{3}$ \\ 'Department of Earth Sciences, Dalhousie University, Halifax, Nova Scotia B3H 3J5, Canada \\ ${ }^{2}$ Memorial University of Newfoundland, St. John's, Newfoundland AIB 3X5, Canada \\ 'Department of Geology, Acadia University, Wolfville, Nova Scotia BOP IXO, Canada}

The Makkovik Province was part of a 1.9-1.75 Ga orogen at the margin of the Archean North Atlantic Craton during assembly of Laurentia-Baltica. Passive margin evolution ended with mafic volcanism at $2178 \mathrm{Ma}$ and the transition to an active margin was signalled $165 \mathrm{~m} . y$. later by foredeep sedimentation (craton + Terrane-I detritus) accompanying oceanward (SE/SW?) subduction. Arrival of Terrane-I resulted in ductile reworking of the craton edge by $1896 \mathrm{Ma}$ and thin-skinned 
thrusting with cratonward transport (decreasing deformation towards the craton interior).

A flip to cratonward (NW) subduction established an Andean-type arc within the reworked craton (parautochthon) by $1895 \mathrm{Ma}$. Arc emplacement accompanied oblique (dextral) convergence as late as $1857 \mathrm{Ma}$ and may have extended outboard (SE) across the postulated accreted Terrane-I. Batholith construction within the parautochthon exploited old structures favourably oriented for extension and thermal softening by the batholith allowed deformation in country rock and parautochthon margins (shear zones) during dextral transpression.

Outboard (SE), bimodal Upper Aillik Group (UAG) volcanism at $\sim 1860 \mathrm{Ma}$ accompanied rifting of arc, parautochthon and (?) Terrane-I. Detritus originating in the arc (granite cobbles) at the rift flanks supplemented epiclastic sedimentation in the UAG basin. Foliated granite xenoliths in late net-veined mafic sills likely represent basement to UAG formed of rifted arc or Terrane-I. Abundant metamorphosed mafic dykes cutting the UAG demonstrate that magmatism during rifting/strike-slip persisted after dated volcanism. The oldest granites $(\sim 1840$ $\mathrm{Ma}$ ) in the Cape Harrison domain (Terrane I?) may be related to arc formation continuing on the outboard edge of the rift.

Inversion of the Aillik rift occurred during a hiatus (1860-1810 $\mathrm{Ma}$ ) in igneous activity in UAG and parautochthon. It re- sulted from accretion of Terrane-II (Cape Harrison domain?) and caused northwest, cratonward thrusting of high grade gneiss and UAG. Opposed crustal and mantle reflectors are related to these latest events. While definitive thrust-related structures are only locally preserved, most regional UAG structures show evidence of one or more transpressive episodes.

Renewed anatexis and plutonism between $\sim 1810$ and 1800 Ma marked the beginning of successive episodes of intra-plate granite plutonism and deformation restricted to narrow belts. An example is dextral strike-slip along the inboard margin of the inverted rift at $1784 \mathrm{Ma}$ and coeval parautochthon plutonism. Widespread 1715 to 1720 Ma plutonism accompanied low-grade dextral transtension at the parautochthon-craton boundary and sinistral-strike slip belts formed during or before empacement of 1650 Ma plutons. These episodes of late, heterogeneneous strike-slip may have decoupled early-Labradorian syn-magmatic extension and compression from the Nain Archean craton. Net-veined mafic sheets, emplaced throughout the parautochthon and UAG between 1720 and $1650 \mathrm{Ma}$, are postulated to be a by-product of the mantle thermal anomaly that accompanied one episode of intra-plate granitic plutonism. A seismically transparent upper crust (intraplate granites) and a basal high velocity zone (mafic underplate) formed during this time of crustal growth.

\section{Crustal structure and history from patterns of Lithoprobe seismic data from Newfoundland, Labrador and adjacent areas}

\section{Jeremy Hall}

Department of Earth Sciences, Memorial University of Newfoundland, St. John's, Newfoundland A1B 3X5, Canada

Over the last 15 years, nearly $10,000 \mathrm{~km}$ of seismic profile data have been collected onshore and offshore in eastern Canada by LITHOPROBE and the Frontier Geoscience Program of the Geological Survey of Canada. These data have provided a wealth of information about present crustal structure, especially with regard to crustal thickness, and the gross internal fabrics. The Paleozoic Appalachian orogen in Newfoundland has an 'anti-root' - the crust is nearly $10 \mathrm{~km}$ thinner below the orogen than below its margins. By contrast the early Proterozoic Torngat orogen retains a $10 \mathrm{~km}$ deep root into the mantle. Proterozoic orogens in Labrador generally show consistent internal crustal fabrics, from the Meozoic unconformity down to the Moho. The Appalachian orogen shows consistent fabrics in the mid- and lower-crust but a 'foggy' zone in the upper crust. These features will be illustrated, and attempts made to account for them, in terms of the extent of collision and later collapse.

\section{Did lapetus sea-floor spreading begin at $\sim 570$ Ma? Paleomagnetic evidence from the Skinner Cove Volcanics of western Newfoundland}

\section{J.P. Hodych and P.J.A. MacCausland \\ Department of Earth Sciences, Memorial University of Newfoundland, St. John's, Newfoundland A1B 3X5, Canada}

The Skinner Cove Volcanics of western Newfoundland have previously yielded a U-Pb zircon age of $550 \pm 3 \mathrm{Ma}$. Their remanent magnetization is shown to be primary by an intraformational conglomerate test and yields a paleolatitude estimate of $19^{\circ} \mathrm{S} \pm 9^{\circ}$. This should represent the paleolatitude of the Iapetan margin of Laurentia at $550 \mathrm{Ma}$ (as the position of the Skinner Cove Formation as a slice in the Humber Arm Allochthon implies original adjacency to underlying slices of Laurentian margin sediments). Comparison with other Laurentian paleomagnetic data from $\sim 580$ to $\sim 520 \mathrm{Ma}$ implies that Laurentia moved very rapidly northward from the south polar region during the latest Neoproterozoic. If so, the start of this rapid northward movement at $\sim 570 \mathrm{Ma}$ likely marks the onset of Iapetus sea-floor spreading between Laurentia and Gondwana. This does not conflict with the Laurentian margin sedimentation record if submergence of the margin was delayed until $\sim 550 \mathrm{Ma}$, perhaps because magmatism at $\sim 570 \mathrm{Ma}$ caused buoyant underplating of the margin. 


\section{Gabbros, metagabbros and waves in the continental crust}

\section{Chuck Hurich, Aphrodite Indares and Sharon Deemer \\ Department of Earth Sciences, Memorial University of Newfoundland, St. John's, Newfoundland A1B 3X5, Canada}

Seismic velocities are an important source of data on the structure and composition of the continental crust. The observation that seismic velocities increase with depth supports the common model of a continental crust that is increasingly mafic with depth, featuring an upper crust dominated by silicic and intermediate rocks and a lower crust dominated by mafic rocks. However, interpretation of seismic velocities is complicated by the fact that velocity is dependent on both composition and metamorphic grade. Gabbros and metagabbros exposed in the Churchill and Grenville provinces of eastern Quebec and western Labrador provide the opportunity to investigate the relative importance of composition and metamorphic grade in determining the velocity, density and reflectivity structure of the continental crust. Unmetamorphosed examples of these gabbros occur in the Churchill Province north of the Grenville Front and metamorphosed examples ranging from greenschist facies though lower and upper amphibolite, granulite and eclogite facies occur in the Gagnon and Molson Lake terranes and the Manicouagan Imbricate Zone of the Grenville Province. To evaluate the relative contribution of compositional variation and metamorphic grade to the physical properties of the crust, we use a generic crustal model defined by proportional mixing of granite/granitic gneiss, anorthosite/gabbroic anorthosite and gabbro/metagabbro. The metamorphic grade is based on a geotherm representing a surface heat flow of $80 \mathrm{~mW} / \mathrm{m}^{2}$. Due to the relative stability of their dominant mineral assemblages, the granitic and anorthositic portions of the model undergo only modest mineralogic modification during metamorphism. The dominant metamorphic variations are expressed in the gabbroic portion of the crustal model. Velocity profiles for the crustal model indicate that although both composition and metamorphic grade play a role in increasing velocity with depth, metamorphic grade plays the dominant role in the middle and lower crust. Reflectivity models generated using a two-stage Monte Carlo simulation based on the generic crustal model provide probability distribution functions for potential reflection coefficients. These models also indicate that metamorphic grade plays a major role in the reflectivity structure of the crust. The models predict significant increases in reflectivity at the transition between lower and upper amphibolite facies and at the transition between granulite and eclogite facies. The results of the velocity and reflectivity models indicate that attention must be paid to both composition and metamorphic grade during the interpretation of wide-angle and normal-incidence seismic data.

\section{Tectono-thermal evolution of deep crust in a Mesoproterozoic continental collision setting: the Manicouagan example}

\section{Aphrodite Indares \\ Department of Earth Sciences, Memorial University of Newfoundland, St. John's, Newfoundland AIB 3X5, Canada}

Exposure of high-P metamorphic rocks in continental collision belts provides invaluable information on the evolution of deep crust and on crust-mantle interactions during orogenic processes. In the Mesoproterozoic Grenville Province, a prime example is the Manicouagan Imbricate Zone (MIZ), discovered in 1992 in the context of a Lithoprobe-funded project, that experienced high-P-T conditions during a Grenvillian crustal shortening event at ca. 1.0 Ga. MIZ is located west of AGLithoprobe line $n^{\circ} 51$ at the southern margin of the so called "Parautochthonous belt" of the Eastern Grenville Province, structurally above Paleoproterozoic supracrustals and their archean basement (Gagnon terrane). To the south it is overlain by "allochthonous" units that were at high to mid-crustal levels at ca. 1.0 Ga. MIZ comprises igneous rocks with intrusion ages ranging from Labradorian to Grenvillian, broadly representative of major events responsible for the makeup of the Province as a whole, that are correlative with "allochthonous" units. It is characterized by P-conditions locally up to 1800 MPa under a high-T regime $\left(850-900^{\circ} \mathrm{C}\right)$ and by synmetamorphic mafic intrusions of tholeiitic within-plate signature. These features attest to a major thermal perturbation at the base of the thickened crust and emplacement of asthenospheric melts that are interpreted as a result of drastic thinning of the lithospheric mantle and rise of asthenosphere close to the crust-mantle boundary, at some stage of the $1.0 \mathrm{Ga}$ crustal shortening event. MIZ has the structural configuration of a thrust stack, with fabrics related to northwest-directed thrusting (lower levels), overlain by units showing evidence of "orogen parallel" extension (middle levels), and top-to-the-southeast extension (opposite to the general thrust direction, upper levels). Exhumation of such a deep crustal section as MIZ has been likely controlled by: (a) crustal weakening due to high T-conditions combined with gravitational instability due to removal of lithospheric mantle; and (b) the presence of a crustal-scale ramp (basement in Gagnon terrane) along which tectonic transport was channeled, leading to extrusion from underneath the "allochthonous" units by northwest-directed thrusting complemented by extension at the top the pile. Thinning of lithospheric mantle has been invoked to explain a variety of features in Phanerozoic continental collision belts and, more recently, in the central Grenville Province. However, data used to support this mechanism have mainly come from middle to high levels of subsequently thinned crust. MIZ is unusual in that it allows investigation of thermally perturbed deep crustal levels. 


\title{
One hundred and eighty million years of crustal growth in the Makkovik Province, Labrador
}

\author{
John Ketchum ${ }^{1}$, Nick Culshaw ${ }^{2}$ and Sandra Barr ${ }^{3}$ \\ ${ }^{1}$ Department of Earth Sciences, Memorial University of Newfoundland, St. John's, Newfoundland A1B 3X5, Canada \\ ${ }^{2}$ Department of Earth Sciences, Dalhousie University, Halifax, Nova Scotia B3H 3J5, Canada \\ ${ }^{3}$ Department of Geology, Acadia University, Wolfville, Nova Scotia BOP IXO, Canada
}

The Paleoproterozoic Makkovik Province of eastern Labrador and the correlative Ketilidian mobile belt of southern Greenland preserve vestiges of a $\sim 1.9$ to $1.72 \mathrm{Ga}$ accretionary orogen along the southern margin of the North Atlantic craton (NAC). Both belts contain reworked Archean rocks and preorogenic supracrustal units in the north, and Paleoproterozoic arc-related plutons and volcano-sedimentary successions in the south. Major transcurrent shear zones at Kaipokok Bay, Labrador and Kobberminebugt, Greenland, mark the boundary between these fundamental lithotectonic domains.

$\mathrm{U}-\mathrm{Pb}$ geochronology has proven an important investigative tool in unravelling Makkovikian orogenic history, particularly when sampling strategy is linked to detailed structural and geochemical studies. Oldest Paleoproterozoic rocks in the northern Makkovik Province are 2235 Ma diabase dykes, and younger platformal rocks of the Lower Aillik Group, both which are interpreted to record stretching and subsidence of Archean crust. An overlying mafic metavolcanic unit erupted at $2178 \mathrm{Ma}$, and stratigraphically higher turbiditic wackes deposited after $2013 \mathrm{Ma}$, formed in an oceanic environment that had evolved to a foredeep basin by $\leq 2013 \mathrm{Ma}$. Initial amphibolite-facies deformation of all these units and their Archean substrate at $1896 \mathrm{Ma}$ is attributed to early interaction of juvenile terranes with the NAC margin, and (or) to continental collision in the west. Voluminous granitoid plutonism within the Archean domain between 1895 and 1860, responsible for much of the Island Harbour Bay plutonic suite, occurred in a tectonic setting marked by amphibolite-facies thrusting but dominated by dextral transcurrent shearing. The latter part of this period coincides with earliest felsic volcanic activity in the Upper Aillik Group, an important component of the accreted juvenile terrane(s).

$\mathrm{The} \mathrm{U}-\mathrm{Pb}$ data indicate renewed granitoid plutonism and deformation between 1840 and $1785 \mathrm{Ma}$, with crustal anatexis, amphibolite- to greenschist-facies fabric development, and an evolution from calc-alkaline to A-type plutonism representing the dominant themes. Northwest- and southeast-directed thrusting within the juvenile terranes likely also played an important role. Deformation within the Archean block was increasingly localized within dextral shear zones (some which represent reactivated older thrusts), and the centre of plutonic and volcanic activity appears to have migrated southward during this period. A foliated tonalite in the Cape Harrison domain (southern Makkovik Province) yields an emplacement age of $1817 \mathrm{Ma}$, suggesting the presence of a north-dipping subduction zone beneath the accreted terranes at this time.

A-type granitoid bodies throughout the Makkovik Province are in part attributed to ca. 1720 Ma post-orogenic plutonism. A 1715 Ma megacrystic granite of the Island Harbour Bay plutonic suite is a product of this event, with a redefinition of this suite clearly indicated. Our U-Pb data and related studies demonstrate a longevity of plutonic and tectonometamorphic activity in the Makkovik Province, and invite comparisons with the Canadian Cordillera where juvenile terrane accretion and lateral tectonic displacements are hallmarks of North American crustal growth.

\section{A new interpretation of the stratigraphy, structure and tectonic evolution of the Wild Bight Group, northwestern Exploits Subzone, Newfoundland Appalachians: implications for evolution of the Gondwanan Margin}

Kate MacLachlan', Greg Dunning' and Brian O'Brien²

'Department of Earth Sciences, Memorial University of Newfoundland, St. John's, Newfoundland A1B 3X5, Canada

${ }^{2}$ Geological Survey, Newfoundland Department of Mines and Energy, St. John's, Newfoundland A1B 4J6, Canada

The Wild Bight Group and South Lake igneous complex represent a peri-Gondwanan Ordovician accreted oceanic terrane of the central Newfoundland Appalachians. The Wild Bight Group is a sequence of volcanic and volcaniclastic rocks, and the South Lake igneous complex comprises layered gabbro and sheeted dykes intruded by hornblende diorite and tonalite plutons. There are two temporally and genetically distinct periods of arc volcanism in the Wild Bight Group, separated by up to $10 \mathrm{Ma}$. The older volcanic sequence is genetically related to plutonic rocks of the South Lake igneous complex. The two volcanic sequences have been structurally interleaved and the Wild Bight Group does not represent a simple conformable sequence in its present configuration.

The older magmatic rocks formed predominantly between $486 \pm 4$ and $489 \pm 3 \mathrm{Ma}$, and are interpreted to represent the initiation and stabilization of a primitive ensimatic oceanic arc outboard of the Gondwanan margin. The younger sequence of the Wild Bight Group comprises two volcanic successions, the lower one has a calc-alkalic geochemical affinity, and its age is confined to $472 \pm 3$ by felsic tuffs within the succession. The upper volcanic succession has enriched tholeiitic to alkalic within-plate geochemical signatures, and geochemically related gabbro sills were dated at $470 \pm 5$ and $471 \pm 4 \mathrm{Ma}$. The younger sequence of the Wild Bight Group is interpreted to represent a volcanic arc that formed on or immediately adjacent to thinned continental crust of the Gondwanan margin, and was subsequently rifted.

Blocks in melanges and debris flows within the younger succession have geochemical signatures which indicate that they were derived from both the older and younger volcanic sequences of the Wild Bight Group. This suggests that the older arc formed part of the substrate on which the younger sequence developed. Intrabasinal uplifts exposed the older substrate which then provided a source of detritus for the 
younger basin. The occurrence of a Precambrian detrital zircon in a volcaniclastic unit of the younger sequence suggests that there may have been an even older component to the uplifted substrate. The uplifts are interpreted to result from horsts and grabens formed in an extensional back arc and subsequent arc rift setting. In most places the contact between the older and younger sequences is structurally modified, but locally there may be an original stratigraphic contact preserved; however, the nature of the contact is equivocal.

The tectonomagmatic evolution of the Wild Bight Group and South Lake igneous complex has four main stages: firstly, formation of a primitive ensimatic arc outboard of the Gondwanan margin, by westward (present coordinates) subduction; secondly arc/continental margin "collision", which involved attempted subduction of the thinned continental margin, and resulted in the termination of westward subduction; thirdly, initiation of a second subduction zone outboard of the continental margin, but with the opposite polarity, such that the subsequent arc developed on the composite margin; and finally, arc rifting which formed an extensive marginal basin.

There are lithological, structural and stratigraphic differences between ophiolites and volcanic rock packages in the
Exploits Subzone interpreted to be correlative with the older ensimatic sequence of the Wild Bight Group, and late Arenig to Llanvirn volcanic/volcaniclastic and epiclastic sequences which are interpreted to be correlative with the younger sequence of the Wild Bight Group. These differences suggest that the degree to which both the Tremadoc to early Arenig ensimatic arc, and the younger late Arenig to Llanvirn arc interacted with the Gondwanan margin, varied considerably along strike. This variation is interpreted to be related to the presence of a promontory on the Gondwanan margin, as suggested by previous workers. The degree of arc rifting is interpreted to be related to the extent of continental substrate in the late Arenig arc. The Exploits Subzone can be divided into two Ordovician tectonic zones, one in the east and south which underwent an important compressional event during the middle to late Arenig (Penobscot Orogeny), but only minor late Arenig to Llanvirn/Llandeilo extension, and the other in the north and west with the opposite characteristics. The boundaries of these zones are likely gradational, but roughly coincide with post-Ordovician structures which have been used to subdivide the Dunnage zone in the past.

\section{The Exploits Group in the context of the Exploits Subzone}

\section{Brian H. O'Brien \\ Geological Survey, Newfoundland Department of Mines and Energy, St. John's, Newfoundland A1B 4J6, Canada}

The Early-Middle Ordovician volcanosedimentary rocks of the Exploits Group were tectonically linked to other variably-aged arc and back-arc supracrustal sequences and deformed arcroot and ophiolitic complexes in the western Exploits Subzone prior to the Late Ordovician deposition of the Badger Group. All these rocks are interpreted to have formed in the extended oceanic crust of a marginal basin which was bounded on both sides by early and mid Ordovician subduction zones. During episodic crustal stretching events, Ordovician depocentres migrated with time across and along the marginal oceanic basin. Most were situated seaward of the compressional forearc sliver and the main Penobscot ocean-continent collision zone, which lay to the south of the Dunnage Mélange.

It is postulated that the volcanic edifice of the western Exploits Subzone arc complex was split to form Early Ordovician rift basins which were filled with pyroclastic and epiclastic debris. Using present coordinates, these originally northwest-elongated depocentres developed northeast-trending subbasin margins in the Middle Ordovician, when small promontories may have formed on the northwest-trending segments of the Early Ordovician island arcs. These remnant Iapetan basins were partially or completely closed as a consequence of Silurian transpressional deformation. During the early stages of the oblique Silurian collision between composite Gondwana and composite Laurentia, an orogen-parallel convergence vector was dominant. At this time, the Exploits Subzone arc complexes were translated alternatively southwestward and northeastward within bivergent oblique-slip thrust systems, which were strongly influenced by the Ordovician configuration of the intra-arc rift asins.

\section{Lithoprobe East and the Newfoundland Appalachians: old questions answered and new questions raised}

\section{Garry Quinlan \\ Department of Earth Sciences, Memorial University of Newfoundland, St. John's, Newfoundland A1B 3X5, Canada}

At the time when the Lithoprobe East transect was initiated in the mid-1980's, significantly less was known about the structure of the Newfoundland Appalachians at depth than was known about its surface geology. In the intervening years there has been a wide range of new data collected either under the auspices of Lithoprobe or directly influenced by Lithoprobe efforts. Some of these new results led to revised interpretations of surface geology, and some provided previ- ously unavailable insights into structure and composition of the deep crust beneath the orogen.

This presentation will provide an overview of how Lithoprobe has changed both our understanding of the Newfoundland Appalachians, and the questions being asked about this orogen. The main focus of the presentation will be on crustal-scale aspects of the Newfoundland Appalachians. 


\title{
Mesoproterozoic arc and backarc deposits on SE Laurentia: the view from the Grenville Province
}

Toby Rivers

Department of Earth Sciences, Memorial University of Newfoundland, St. John's, Newfoundland A1B 3X5, Canada

Despite partial obliteration during the Grenvillian Orogeny, evidence has been accumulating during the last few years for the existence of a Mesoproterozoic ( $1500-1220 \mathrm{Ma})$ continental-margin magmatic arc on SE Laurentia. Available data indicate that the arc was up to $200 \mathrm{~km}$ wide and extended at least from Labrador to Texas, suggesting that it was of Andean proportions. In this context, the coeval supracrustal and plutonic units that formed inboard of the arc have recently been interpreted as backarc deposits that were developed on and/or in variably stretched continental crust. Examples include: (1) coast-parallel mafic dyke swarms; (2) bimodal volcanics and continental sediments; (3) continental flood basalts; and (4) pillow basalts and associated marine sediments.
The best-known and most extensive supracrustal backarc units occur in several imbricated basins in the Central Metasedimentary Belt of southern Ontario and Quebec. Most of these units were deposited on stretched continental crust, but the presence of a relict ophiolite indicates that backarc rifting resulted in the formation of spreading centres and the generation of ocean crust locally. Calc-alkaline igneous rocks formed as a result of subduction of this crust during basin closure. In Labrador and eastern Quebec, backarc extension appears to have been more limited, and all deposits, including the Michael-Shabogamo gabbros, the Wakeham Supergroup and the Seal Lake Group, are inferred to have formed on continental crust.

\section{Mesozoic extensional tectonism on the northern Grand Banks as expressed at the Hibernia Oilfield}

\author{
Iain Sinclair \\ Hibernia Management and Development Corporation, St. John's, Newfoundland
}

The Grand Banks region, offshore eastern Newfoundland, experienced multiple episodes of rifting during the Mesozoic. Extension of the continental crust resulted in widespread deformation, dominated by growth of normal faults. These faults, in turn, controlled subsidence of numerous sedimentary basins and rotation of intra-basin structures. Episodic rifting culminated in the staged breakup of Pangaea and seafloor spreading along new segments of the North Atlantic Ocean. Each rift episode evolved under unique stress conditions characterized by changing fault orientations and slip directions. Mesozoic extension created the Hibernia structure on the western margin of the Jeanne d'Arc Basin while subsidence during the subsequent passive episode resulted in maturation of Upper Jurassic source rocks and expulsion of the oil trapped in the faulted Hibernia anticline.

The first Mesozoic episode of extension is interpreted to have generated a series of northeast-trending, en echelon faults adjacent to the Hibernia Oilfield. The second rift episode spanned the Late Jurassic to Early Cretaceous and resulted in linkage of these en echelon faults into a single, albeit geometrically complex, normal fault. Numerous smaller faults trending north to south also formed during this time of basin margin uplift and deposition of coarse-grained sediments (i.e., the Jeanne d'Arc and Hibernia reservoir facies). The youngest episode of extension occurred late in the Early Cretaceous and caused the highest degree of deformation observed, both in terms of fault offset and block rotation. Normal faults, trending northwest-southeast, grew throughout the Jeanne d'Arc Basin, synchronous with deposition of the "Avalon" reservoir sandstones. Additionally, there is evidence of oblique-slip re-activation along the basin margin at Hibernia. The age limits and the character of faulting (thin versus thick-skinned extension) associated with this culmination of structural deformation, however, remain subjects of continuing study.

\section{The Cinq-Cerf gneiss: evidence for polycyclic reworking of the westernmost Avalonian basement in the Newfoundland Appalachians}

Pablo Valverde-Vaquero

\author{
Department of Earth Sciences, Memorial University of Newfoundland, St. John's, Newfoundland A1B 3X5, Canada
}

The Cinq-Cerf gneiss is part of the westernmost extent of the Late Precambrian-Early Ordovician basement block of the Hermitage Flexure. U-Pb ages from the previously undated Cinq-Cerf gneiss provide a strong link with the Precambrian rocks of Grey River (Hermitage Flexure) and the Connaigre peninsula (Avalon Zone s.s.).

The youngest unit in the Cinq-Cerf complex is a variably deformed $431.5 \pm 1$ Ma granite-granodiorite with amphibolite and gneissic enclaves, cross-cut by mafic dykes deformed in upper greenschist facies (420 Ma, titanite). Syn-magmatic deformation followed by variable greenschist facies mylonitization mimic a high-grade gneissic complex. The 431
Ma granite intruded into older rocks, including weakly deformed metagabbro/diorite (557+14/-5 Ma) and hornblendebearing granodiorite $(584+7 /-6 \mathrm{Ma})$. The gneissic fabric in a highly strained $675+12 /-11$ Ma granitic orthogneiss is crosscut by the $431 \mathrm{Ma}$ granite. This observation, coupled with the preservation of primary magmatic features in the $584 \mathrm{Ma}$ granodiorite, suggests an intense 675 to $584 \mathrm{Ma}$ deformational event.

Volcanism at the base of the nearby low-grade, Whittle Hill sandstone was coeval with the intrusion of the $584 \mathrm{Ma}$ granodiorite, raising the possibility of a basement-cover relationship with the Cinq-Cerf gneiss. This Late Precambrian 
volcanosedimentary sequence was intruded by Penobscottian (499-494 Ma) plutons, suggesting the involvement of Avalonian rocks (s.s.) in the Early Ordovician evolution of the peri-
Gondwanan margin of the Iapetus Ocean in the Newfoundland Appalachians.

\title{
The Torngat Orogen of northern Labrador and its role in the evolution of northeast Laurentia
}

\author{
R.J. Wardle and B. Ryan \\ Geological Survey, Newfoundland Department of Mines and Energy, St. John's, Newfoundland A1B 4J6, Canada
}

The development of northern Labrador in the period 1.9 to $1.74 \mathrm{Ga}$ was controlled by the oblique collision of the Archean Nain craton with an Archean-Paleoproterozoic block, known as the core zone, to form the Torngat Orogen. The collision of the two Archean blocks sandwiched a narrow, axial belt of juvenile metasedimentary crust (the Tasiuyak gneiss, probably representing the remnants of an accretionary complex) and calk-alkalic, arc-related plutonic rocks. As such, the orogen represents a doeply eroded, ancient analog for modern small-scale transpressional orogens such as the California Coast Ranges and Pyrenees.

Development of the Torngat Orogen followed the sequence: (1) rifting of the Nain craton ca. 2.2 to $2.1 \mathrm{Ga}$ in association with generation of granite-anorthosite suites and mafic dyke swarms; (2) ocean closure and arc magmatism ca. $1.91 \mathrm{Ga}$; (3) initial deformation (arc/Nain collision?) ca. $1.86 \mathrm{Ga}$; (4) NainCore zone collision and overriding of core zone ca. 1.84 to $1.83 \mathrm{Ga}$, followed and accompanied by intense sinistral shearing 1.845 to $1.82 \mathrm{Ga}$; and (5) renewed outward vergent thrusting, probably related to more distal collisions in the evolving orogenic plexus of northeast Laurentia between 1.82 and $1.74 \mathrm{Ga}$.

A structural cross-section across the northern Torngat Orogen reveals a doubly vergent profile, centered on the Abloviak shear zone, that was constructed through multistage thrusting and sinistral ductile shearing between 1.86 and 1.74 $\mathrm{Ga}$. Comparisons with geodynamic model templates suggest that this may have been achieved by a combination of plug uplift due to frontal continental collision, and flower-structure development as the result of transcurrent motion on the Abloviak shear zone. A recent refraction seismic profile across the northern part of the orogen has revealed a pronounced crustal root beneath the orogen, possibly representing the remnants of thickened and partially subducted (core zone?) continental crust. As the Torngat Orogen is traced to the south, the Abloviak zone dies out, as does the Tasiuyak gneiss, and sinistral shearing steps southwestwards into the core zone as a number of en echelon shear zones. The suture in the far south is marked only by a rather cryptic juxtaposition of Nain craton and core zone Archean gneisses that probably represents the initial character of the suture prior to Abloviak overprint. The sinistral shearing, therefore, postdated initial collision and accretion on the Nain margin but may have been synchronous with core zone collision. Whilst the sinistral shear zones are impressive in size, their en echelon character and limited strike length suggests that they probably do not represent very large-scale lateral translations.

A noteworthy feature of Torngat Orogen (and other Paleoproterozoic orogens of NE Laurentia), is the lack of the late- to post-orogenic granites that predominate in many other orogens. A possible explanation is that Torngat Orogen and its neighbours are largely underlain at depth by (refractory?) Archean lithosphere that may have inhibited the melting effects of the delamination and asthenospheric upwelling processes that are generally thought to initiate post-collision magmatism.

The Torngat Orogen may be traced north into Baffin Island where it appears to separate the Trans-Hudson Orogen of Baffin Island from the Nagssugtoqidian Orogen of west Greenland. There are, however, several problems of correlation which will be discussed, foremost among which is the degree to which juvenile Trans-Hudson crust of Baffin Island extends into Labrador/Quebec.

\section{Grenville, Appalachian, and Atlantic tectonics in eastern Canada: the Harry Hibbs Effect}

Hank Williams

Department of Earth Sciences, Memorial University of Newfoundland, St. John's, Newfoundland A1B 3X5, Canada

Multiple ocean opening-closing cycles along the same seam is called the Harry Hibbs Effect, honouring a famous Newfoundland accordionist. In eastern Canada, the Precambrian Grenville Orogen, the Paleozoic Appalachian Orogen, and the modern Atlantic continental margin are all parallel and divisible into parallel zones that express their origins through successive Wilson cycles; the Precambrian Uranus, the Paleozoic Iapetus, and the modern Atlantic cycles, respectively.

Analyses of the Atlantic margin and Appalachian miogeocline are complementary. Rifting and passive margin stages of the Atlantic margin have counterparts in the Appalachian miogeocline, including the important breakup unconformity that separates the rifting stage from the drifting stage of continental margin development. Outboard terranes of the Appa- lachian Orogen were accreted during Iapetus closing in the Ordovician and Silurian.

The Grenville Orogen lacks contemporary stratigraphy. Apart from a few younger groups and plutons in the southeast, almost all its rocks were metamorphosed and deformed previous to Grenville Orogeny. Deep seismic reflection surveys confirm surface observations that the orogen is asymmetric, one-sided and consists of southeast dipping crustalscale imbricates bounded by northwest directed, broad ductile thrust zones. These are underlain by a basal crust-penetrating thrust expressed at the surface as the Grenville Structural Front. Latest analyses distinguish an Exterior Thrust Belt, divided into a parautochthon and allochthon, and an Interior Magmatic Belt. Comparisons with the Appalachian Orogen 
give some insight into Grenvillian orogenic phases and rationalizes its orogen-parallel belts.

Some offsets of the Atlantic margin mimic boundaries between Paleozoic lower crustal blocks or Grenville features. The Paleozoic Dover Fault projects into the Charlie Gibbs Fracture Zone. The Grenville Structural Front is expressed in the Atlantic margin offset at the Cartwright Arch and its seaward prolongation into the Cartwright Fracture Zone. Zigzag, orthogonal shapes of rifted continental margins controlled the shapes of the ensuing Grenville and Appalachian collisional orogens. Examples of ancestral controls are common.

\section{Subsurface geology, paleontology and thermal maturity of Hunt et al. Port au Port \#1 and Long Point M16, and their bearing on the structural history of the Port au Port Peninsula}

\section{S. Henry Williams and Elliott T. Burden \\ Department of Earth Sciences, Memorial University of Newfoundland, St. John's, Newfoundland A1B 3X5, Canada}

With recent hydrocarbon exploration in western Newfoundland, significant data have emerged shedding new light on the region. In the last decade, a number of geophysical and structural studies have indicated widespread thrusting and triangle zones and the probability that all of the Early Paleozoic rocks of the region are actually allochthonous. A number of these structures have good potential for hydrocarbon traps. These observations were complemented by the results from several exploration wells drilled over the past four years. During this recent round of investigation, we have been involved with drilling projects by Hunt, PanCanadian, Mobil, Delpet and LMX Resources; of these, confidentiality restrictions have now been lifted for Hunt-PanCanadian Port au Port \#1 and Hunt-PanCanadian-Mobil Long Point M16 wells.

Port au Port \#1 and Long Point M16 were drilled to test radically different subsurface geology and structure. Models suggested that Port au Port \#1 would pass through Paleozoic platform carbonates and into the Long Range Complex, before re-entering the Paleozoic in the footwall of the Round
Head Thrust. Long Point M16, on the other hand, was expected to pass through a thick package of deep marine sediments of the Humber Arm Allochthon before passing into "autochthonous" platform carbonates below. Play models envisaged reservoir development related to karstification and dolomitization of early Ordovician carbonates, with early Ordovician black shales of the Humber Arm Allochthon as the most likely source.

Our work provided data on three different aspects: (1) age and confirmation of stratigraphic succession in the wells, (2) estimates of thermal maturity and correlation with surface surveys, and (3) modelling of thermal and burial histories and constraints on age of structural deformation. Paleontology proved to be a key to the identification of a number of stratigraphic levels in lithologically similar carbonates and clastics, recognition of major structures, and guidance on source rock maturation and burial history; this demonstrates the need for continued use of biostratigraphy and thermal maturity studies during hydrocarbon exploration in the complex terranes of the Canadian Appalachians.

\section{Metallogenic principles as applied to the tectonic evolution of Newfoundland}

\section{Derek H.C.Wilton \\ Department of Earth Sciences, Memorial University of Newfoundland, St. John's, Newfoundland A1B 3X5, Canada}

In its simplest definition, metallogeny has been described as the study of the factors (especially tectonic or large scale) that control the distribution of mineral deposits in space and time. In an orogenic belt such as the Appalachian Orogen in Newfoundland, the temporal and spatial distributions of mineral deposits involve variable tectonic regimes related by large scale plate tectonic processes. As a corollary, because these tectonic processes define the mineralization style, recognition of hither-to-fore unknown styles of mineralization can lead to the definition of new tectonic paradigms. It has been postulated by others that there are three main controls on the evolution of mineral deposits, viz.: (1) evolution of the hydrosphere and atmosphere, (2) decreasing global heat flow, and (3) large scale tectonic trends. Points (1) and (2) suggest that certain types of mineral deposits are restricted to specific periods in Earth history. In the case of the Appalachian Orogen in Newfoundland, the only major factor affecting mineral deposit formation is (3) long-term tectonic trends and these trends actually determine which different styles of mineralization develop as related to specific periods in the evolution of the orogen. These trends themselves are cyclic (i.e., are reflections of the Wilson cycle). Metallogeny in Newfoundland has typically been thought of as being pre-accretional, accretional, and post-accretional with respect to the Appalachian Orogen. In the past decade, however, earlier periods of mineralization related to metallogenic cycles within bounding Precambrian blocks, in particular the Gondwanan margin (i.e., pre-Appalachian Orogen), have been recognized extending the perceived economic potential of the island. Delineation of previously unknown styles of mineralization within the orogen itself has also led to new tectonic models for the orogen. 